\title{
A Review on the Potential Effect of Lime on Soil Properties and Crop Productivity Improvements
}

\author{
Tolossa Ameyu \\ Ethiopian Institute of Agricultural Research; Jimma Research Center P.O Box 192, Jimma, Ethiopia
}

\begin{abstract}
The review summarizes the literature and the current knowledge on the effect of lime on soil chemical properties and crop productivity. Most of investigators confirmed that lime application could improve the chemical and biological properties of the soils. The long-term lime application trials result in increased soil chemical properties. In addition, due to its multiple positive effects on the chemical and biological soil properties, lime contributes to increase crop productivity and crop quality. Predominantly because of the slow work of lime to make the nutrients available for crops lime-combined fertilization schemes often show good results. Thus, for sustainable agricultural systems within small-scale farming in developing countries like Ethiopia, recommended liming with minimum chemical fertilization can be a good option for developing effective plant-nutrient management strategies in acid soil area.
\end{abstract}

Keywords: Liming, soil acidity, crop productivity, soil chemical property, soil biological property DOI: $10.7176 / \mathrm{JEES} / 9-2-03$

\section{INTRODUCTION}

Soil acidity is a complex of numerous factors involving nutrient deficiencies and toxicities, low activities of beneficial micro organisms, and reduced plant root growth, which limits absorption of nutrients and water (Fageria and Baligar, 2008). The summation of different anthropogenic and natural processes including leaching of exchangeable bases, basic cation uptake by plants, decomposition of organic materials, application of commercial fertilizers and other farming practices produce acidic soils (Brady and Weil, 2002). Soil acidity is a severe problem in high rainfall areas of Ethiopia, and can lead to decline or complete failure of crop production (Abdenna et al., 2007). Therefore, the adjustment and maintenance of soil acidity is very important management of acidic soils to increase crop production using different mechanisms (approaches).

Lime is the major means of ameliorating soil acidity (Anetor and Ezekiel, 2007), because of its very strong acid neutralizing capacities, which can effectively remove existing acid, stimulate biological activity and reduce toxicity of heavy metals. The most efficient crop production on acid soils is the application of both lime and fertilizer, specifically phosphorus. When lime is applied to the soil, $\mathrm{Ca}^{2+}$ and $\mathrm{Mg}^{2+}$ ions displace $\mathrm{H}^{+}, \mathrm{Fe}^{2+}, \mathrm{Al}^{3+}$, $\mathrm{Mn}^{4+}$ and $\mathrm{Cu}^{2+}$ ions from soil adsorption sites resulting in increase in the soil $\mathrm{pH}$, and other than increasing soil $\mathrm{pH}$, lime also supplies significant amounts of $\mathrm{Ca}$ and $\mathrm{Mg}$, depending on the type of liming materials. Indirect effects of lime include increased availability of $\mathrm{P}$, Mo and B, and more favorable conditions for microbially mediated reactions, such as nitrogen fixation and nitrification, and in some cases improved soil structure (Nekesa et al., 2005). Therefore, the objective of this paper is to review the effect of lime on chemical properties of soil and crop productivity improvement.

\section{Potential effects of Lime on some Chemical Properties of Acid Soils Increase of Soil pH and Decrease of Exchangeable Acidity}

Limes are materials containing carbonates, oxides or hydroxide required to apply on acidic soil to raise soil $\mathrm{pH}$ and neutralizes toxic elements in the soil. Liming materials include $\mathrm{CaCO}_{3}, \mathrm{Ca}(\mathrm{OH})_{2}, \mathrm{CaO}$ and others, which vary according to their neutralizing value and degree of fineness (TSO, 2010). Soil reaction is expressed in terms of $\mathrm{pH}$ indicating whether the soil is acidic, alkaline or neutral. Soil $\mathrm{pH}$ measures the molar activity (concentration) of hydrogen ions in the soil solution (Moody and Cong, 2008). Soil pH helps to identify the kinds of chemical reactions that are likely taking place in the soil. It affects nutrient availability and toxicity, microbial activity, and root growth. Most plants grow well at a $\mathrm{pH}$ range of 5.5 to 6.5 and liming is aimed to increase the $\mathrm{pH}$ to this range. Liming is a management practice to reduce the soil acidity and therefore one of the soil fertility management practices (AGRA.2009). When lime is added to acid soils that contain high $\mathrm{Al}^{3+}$ and $\mathrm{H}^{+}$concentrations, it dissociates into $\mathrm{Ca}^{2+}$ and $\mathrm{OH}^{-}$ions. The hydroxyl ions will react with hydrogen and $\mathrm{Al}^{3+}$ ions forming $\mathrm{Al}^{3+}$ hydroxide and water; thereby increase soil $\mathrm{pH}$ in the soil solution. Soil $\mathrm{pH}$ increased significantly from 5.03 in the plots without lime to 6.72 at the lime rate of $3750 \mathrm{~kg} \mathrm{CaCO}_{3} \mathrm{ha}^{-1}$ (Buni.A. 2014).

The experiment conducted at Holeta Agricultural research center showed that the soil results after 2 years of liming is depicted indicated that soil $\mathrm{pH}$ was significantly $(\mathrm{P}<0.05)$ increased and $\mathrm{Al}^{3+}$ was markedly reduced a negligible level (Temesgen, et al 2016). Liming at the rate of $0.55,1.1,1.65$ and $2.2 \mathrm{t} \mathrm{ha}^{-1}$ increased soil $\mathrm{pH}$ by $0.48,0.71,0.85$ and 1.1 units, and decreased $\mathrm{Al}^{3+}$ by $0.88,1.11,1.20$ and 1.19 mill equivalents per $100 \mathrm{~g}$ of soil respectively, which means with successive increase in the amounts of lime, soil $\mathrm{pH}$ values increased with a 
corresponding decrease in exchangeable $\mathrm{Al}^{3+}$ of the soil (Temesgen, et al 2016). Bambara and Ndakidemi (2010a) reported that application of 2 and 3 ton lime $\mathrm{ha}^{-1}$ increased soil $\mathrm{pH}$ in the rhizosphere of Phaseolus vulgaris by 3.2 and 4.9\%, respectively, relative to unlimed soil. Mesfin et al. (2014) reported that application of 0.4 ton lime $\mathrm{ha}^{-1}$ increased soil $\mathrm{pH}$ by $7 \%$ compared to unlimed control. Murata et al. (2002) also reported that application of lime at the rate of 2 ton $\mathrm{ha}^{-1}$ significantly increased topsoil $\mathrm{pH}$ values from 4.6 to 6.0. Meng et al (2004) also showed soil pH increment of 0.64 to 2.14 units due to lime application. Many authors (e.g., Achalu., et al 2012; Álvarez et al., 2009; Fageria, and Baligar, 2008) have reported that liming raises soil $\mathrm{pH}$ and reduce $\mathrm{Al}^{3+}$ concentration.

Exchangeable acidity consists of aluminum or iron, as well as any exchangeable $H$ that may be present in the exchange sites (Bohn et al., 2001). Exchangeable acidity in soils is almost entirely due to $\mathrm{Al}^{3+}$ ions. This is because only $\mathrm{Al}^{3+}$ is a common exchangeable cation in moderately to strongly acidic soils (Bohn et al., 2001). Detoxification of $\mathrm{Al}$ can be achieved by increasing soil $\mathrm{pH}$ through application of agricultural lime which in turn certainly result in decrease in Al solubility thereby minimizes its toxic effect on plants. Achalu et al., 2012 reported application of lime at the rate of 10 ton /ha decreased the soil exchangeable acidity from $2.80 \mathrm{cmol}(+) \mathrm{kg}$ in the control to $0.26 \mathrm{cmol}(+) \mathrm{kg}$ with decrement in exchangeable acidity of about $90.7 \%$. Temesgen et al., (2017) also reported that application of lime and its residual effect highly decreased exchangeable acidity (from the initial level of 1.32 to $0.1 \mathrm{cmol} / \mathrm{kg}$ ) and $\mathrm{Al}^{+3}$ as the level of applied lime rates increased. This decrease may be ascribed to the increased replacement of $\mathrm{Al}$ by $\mathrm{Ca}$ in the exchange site and by the subsequent precipitation of $\mathrm{Al}$ as $\mathrm{Al}(\mathrm{OH})$ 3, as the soil was limed (Havlin LJ, 1999). Moreover, an increase in soil $\mathrm{pH}$ results in precipitation of exchangeable and soluble $\mathrm{Al}$ as insoluble $\mathrm{Al}$ hydroxides thus reducing concentration of $\mathrm{Al}$ in soil solution.
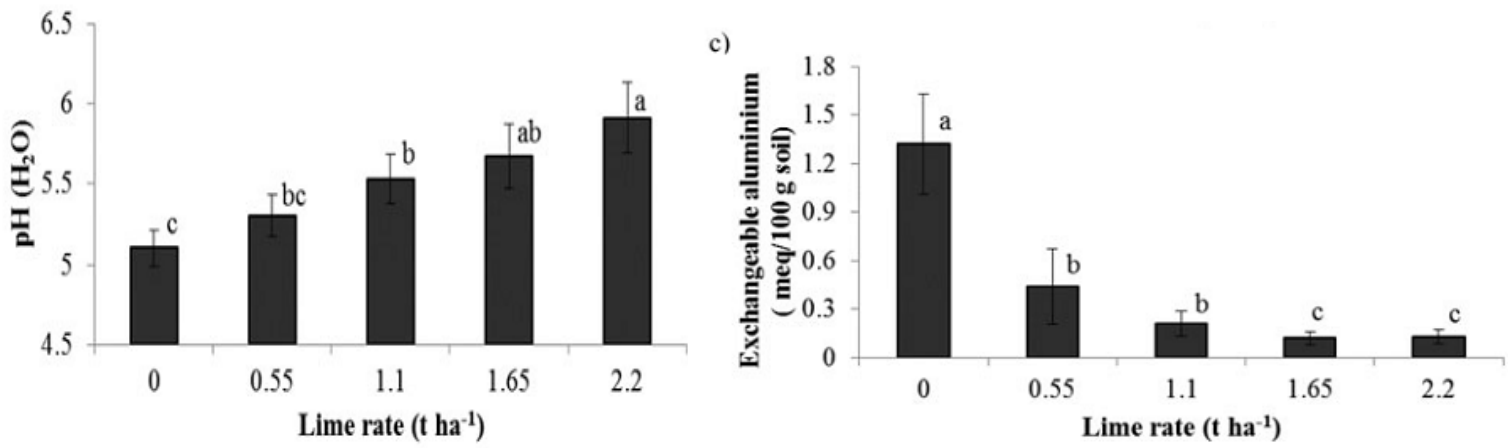

Figure 1: Mean variation of the $\mathrm{pH}$ and Exchangeable aluminium of soils after application of lime (Temasgen et al., 2016)

\section{Increase of Available Phosphorus}

Phosphorus is commonly bound to iron and aluminium oxides and hydroxides through chemical precipitation or physical adsorption (Kochian et al., 2004). The major portion (80-90\%) of mineral P fertilizers applied to the soil cannot be absorbed by plants due to adsorption to Fe oxides/hydroxides, Al hydroxides and due to chemical precipitation. As a result of adsorption, precipitation and conversion to organic forms, only 10-30\% of the applied phosphate mineral fertilizer can be recovered by the crop grown after the fertilization (Syers et al., 2008). Liming of acidic soils could increase soil $\mathrm{pH}$, which enhances the release of phosphate ions fixed by $\mathrm{Al}$ and Fe ions into the soil solution. Achalu et al. (2012) reported that the deficiency of P could be corrected thought liming of acid soil to increase the $\mathrm{pH}$ more than 6 . The increasing of available $\mathrm{P}$ as a result of lime application is due improving soil acidity, and hence, increased availability of P (Kisinyo, 2016). Lime contributed in the release of some amount of fixed $\mathrm{P}$ to the soil, which will be available for the crop. Therefore, agricultural liming materials added to soil is a profitable soil additive and it hydrolyzes $\mathrm{Al}$ and $\mathrm{Fe}$ ions that precipitated with $\mathrm{P}$. Hence, the precipitated phosphate ion released in to the soil solution thereby rendering the phosphate ion available for plant uptake. Liming and thus raising the $\mathrm{pH}$ of acidic soil is generally provide more favorable environments for microbial activities and possibly results net mineralization of soil organic phosphorus. Liming can increase phosphate availability by stimulating mineralization of soil organic phosphorus. 
Table: 1 showing improvement for some of the soil chemical properties as they are affected by different rate of agricultural lime from field experiment at Holeta

\begin{tabular}{llllll}
\hline Lime Kg/ha & $\mathrm{pH}$ & $\mathrm{CEC}\left(\mathrm{cmol}(+) \mathrm{kg}^{-1}\right)$ & $\mathrm{Al}$ & $\mathrm{EA}\left(\mathrm{cmol}(+) \mathrm{kg}^{-1}\right)$ & Ava. P $\left(\mathrm{mg} \mathrm{kg}^{-1}\right)$ \\
\hline 0 & $5.03^{\mathrm{d}}$ & $19.18^{\mathrm{d}}$ & $0.68^{\mathrm{a}}$ & $0.97^{\mathrm{a}}$ & $5.36^{\mathrm{b}}$ \\
1250 & $5.64^{\mathrm{c}}$ & $25.1^{\mathrm{c}}$ & $0.56^{\mathrm{b}}$ & $0.75^{\mathrm{b}}$ & $6.70 \mathrm{a}$ \\
2500 & $6.14^{\mathrm{b}}$ & $31.49^{\mathrm{b}}$ & $0.33^{\mathrm{c}}$ & $0.51^{\mathrm{c}}$ & $7.04^{\mathrm{a}}$ \\
3750 & $6.72^{\mathrm{a}}$ & $33.34^{\mathrm{a}}$ & $0.24^{\mathrm{c}}$ & $0.36^{\mathrm{c}}$ & $6.67^{\mathrm{a}}$ \\
\hline LSD (5\%) & 0.014 & 0.738 & 0.13 & 0.21 & 0.94 \\
CV (\%) & 3.01 & 6.24 & 8.12 & 6.43 & 2.04
\end{tabular}

Means within a column followed by the same letter(s) are not significantly different from each other at $\mathrm{P}=0.05 \%$

(Source: Adane Buni, 2014)

\section{Increase of Exchangeable bases $\left(\mathrm{Ca}^{2+} \mathrm{Mg}^{2+}\right.$ and $\left.\mathrm{K}^{+}\right)$and Cation exchange capacity (CEC)}

The removal of base cations, especially $\mathrm{Ca}$ and $\mathrm{Mg}$, by leaching and erosion results in their replacement by acidic cations like $\mathrm{H}, \mathrm{Al}$ and $\mathrm{Fe}$ on exchange sites and in the soil solution (Johnston, 2004). Activities of exchangeable basic $\left(\mathrm{Ca}^{2+}, \mathrm{Mg}^{2+}\right.$ and $\left.\mathrm{K}^{+}\right)$cations; orthophosphate $\left(\mathrm{H}_{2} \mathrm{PO} 4\right)$, nitrate $\left(\mathrm{NO}_{3}{ }^{-}\right)$and sulfate $\left(\mathrm{SO}_{4}{ }^{2-}\right)$ anions with soil organic matter content and their availability to plant roots might be hampered by acidifying ions (Thomas and Hargrove, 1984). Highly weathered tropical soils such as Oxisols have very low levels of exchangeable Ca and crops grown on such soils exhibit $\mathrm{Ca}$ deficiency when exchangeable $\mathrm{Ca}$ is $<1 \mathrm{cmol} \mathrm{kg}^{-1}$. The application of limestone (calcium carbonate) and or dolomatic lime ( $\mathrm{Ca}$ and $\mathrm{Mg}$ bicarbonate) increases soil exchangeable $\mathrm{Ca}$ and $\mathrm{Mg}$ respectively. With the neutralization of part of the soil acidity by lime application, negative charges of the soil exchange complex are released, as cited by (Achalu et al., 2012) and then occupied by basic cations.

The soils exchangeable $\mathrm{Ca}^{2+}$ ion and CEC of soil showed increments with the increase of applied lime rates and soil $\mathrm{pH}$ (Achalu et al., 2012). This direct relationships between $\mathrm{pH}$, exchangeable $\mathrm{Ca}^{2+}$ and $\mathrm{CEC}$ with the increase of the lime rates is attributed to the applied lime which enhances the concentration of $\mathrm{Ca}^{2+}$ and thereby increases the soil $\mathrm{pH}$ due to the dissociation of agricultural lime and replacement of $\mathrm{H}^{+}$and $\mathrm{Al}^{3+}$ from the soil solution and soil exchange complex. Similarly, the direct relationship of CEC with soil $\mathrm{pH}$ may be attributed to the presence of $\mathrm{pH}$ dependant negative charges which can increase with increasing soil $\mathrm{pH}$ due to applied agricultural lime. A slight increment in exchangeable $\mathrm{Mg}$ and $\mathrm{K}$ was also reported in Nigeria by application of lime $\left(\mathrm{CaCO}_{3}\right)$ on acidic soils (Adetunji and Bamiro, 1994).

The cation exchange capacity (CEC) of a soil represents the total quantity of negative charge available to attract cations in the soil solution. High CEC values are usually associated with humus compared to those exhibited by the inorganic clays, especially kaolinite and Fe, Al oxides (Brady and Weil, 2002). Liming acidic soils indirectly increases the effective cation exchange capacity (ECEC) of soils that contain organic matter or variably charged

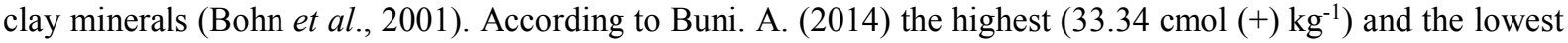
$\left(19.18 \mathrm{cmol}(+) \mathrm{kg}^{-1}\right)$ values of CEC were observed under the highest lime treated and the control plots, respectively. The increase in $\mathrm{CEC}$ due to liming could be attributed to the change in $\mathrm{pH}$ and the release of the initially blocked is amorphous and interlayer substitional negative charge by deprotonation of the variable charge minerals and functional groups of humic compounds caused by $\mathrm{Ca}^{2+}$. The greater amount of negative charge available on the surfaces of these minerals results in the increase in CEC (Pionke HB and Corey RB, 1967).

\section{Effects of lime on soil biological properties}

Soil microbiological properties can serve as soil quality indicators. Soil acidity restricts the activities of beneficial microorganisms, except fungi, which grow well over a wide range of soil pH (Brady NC and Weil RR.2002). Liming acidic soils enhance the activities of beneficial microbes in the rhizosphere and hence improve root growth by the fixation of atmospheric nitrogen because neutral $\mathrm{pH}$ allows more optimal conditions for free-living $\mathrm{N}$ fixation (Stephen PC et al., 2011). It can also suppress pathogens and producing phytohormone; enhancing root surface area to facilitate uptake of less mobile nutrients such as $\mathrm{P}$ and micronutrients and mobilizing and Solubilizing unavailable nutrients (Fageria and Baligar, 2008). According to McBride (1994), increasing soil pH through liming can significantly affect the adsorption of heavy metals in soils. Soil properties such as organic matter content, clay type, redox potential, and soil $\mathrm{pH}$ are considered the major factors that determine the bioavailability of heavy metals in soil (Treder W and Cieslinski G.2005). Hence, liming certainly helps in reducing availability of heavy metals to crop plants.

\section{Effects of lime on crop productivity improvement}

Due to its multiple positive effects on the physical, chemical and biological soil properties, lime contributes to increase of crop productivity and crop quality (Fageria and Baligar, 2008). Plant growth improvement in acid soil is not due to addition of basic cations $(\mathrm{Ca}, \mathrm{Mg})$, but it is due to increasing $\mathrm{pH}$ that reduces toxicity of phytotoxic levels of $\mathrm{Al}$ (Fageria and Beligar, 2008). Long-term field trials proved that lime has an equalizing effect of 
annual/seasonal fluctuations regarding the availability of plant nutrients and thus the final crop yields. Better crop results were often obtained during the second year of lime were applied than the first year (Temesgen et al., 2017). However, crop yields after pure lime application were mostly lower when compared to with mineral fertilization or phosphorus (Temesgen et al., 2017), at least during the first years. This can be explained by the slow reaction of lime with soil, and might be attributed to solubility and downward movement of lime as the time progresses, and normal rainfall with uniform distribution through outgrowing season in second year as compared to first year. Zerihun and Tolera, (2014) reported the increased of faba bean yield ranging from $11 \%$ to $23 \%$, as the function of increasing lime application rates up to $6 \mathrm{t} \mathrm{ha}^{-1}$.

Data collected from soybean showed that liming significantly increased nodule number, nodule volume and nodule dry weight per plant as compared to the un-limed treatment in legume crops (Abubakari, 2016). Temesgen et al. (2017) reported that effect of lime on acid soil amelioration and barley grain yield were the highest during the initial four years, but in the final year grain yield was declined substantially. This yield reduction in the final year may indicate re-acidification of the soil. In Croatia, Andric et al. (2012) also reported increased soybean yield by $44 \%$ as a result of lime application over the control/unlimed treatments. Workneh et al. (2013) reported significant increase in straw yield of soybean by $16.3 \%$, due to soil liming at the rate of $2.6 \mathrm{t} \mathrm{ha}^{-1}$. Application of lime significantly increased root and shoot yields of soybean in Nigeria (Anetor and Akinrinde, 2006), yields of soybean in Brazil (Caires et al., 2006). This might be due to lime enhanced vegetative growth, thereby, enabling the plant to bear higher number of pods than the untreated soil condition, and neutralizing soil acidity by lime, which in turn increases availability of $\mathrm{P}$ for plant uptake, through reduction in its fixation on acid soils.

Moreover, Workneh et al. (2013) reported that the application of lime produced the highest nodule number, nodule volume and nodule dry weight per plants. These authors also reported, the highest number of pods per plant (39.40) was produced when the crop was grown under limed soil. According to the experiment conducted in Nigeria, where $2.0 \mathrm{t} / \mathrm{ha}$ and $1 \mathrm{t} /$ ha lime were applied, the authors recorded $72 \%$ and $48 \%$ increases in yield, respectively, over no lime treatments (Buri et al., 2005). The other experiments was conducted by the same authors by combined lime-phosphorus on an Oxisol and Ustisols with pH ranging from 4.1-4.5 and 4.7-5.4, respectively, also showed a considerable increase in maize grain yield by both lime and phosphorus. The reason might be the increase in $\mathrm{pH}$ and the availability of other essential nutrient elements. More over application of lime improved the ability of the plant to absorb phosphorus, by eliminated Al toxicity, and enhanced the vegetative growth of soybean genotypes, which resulted in increased dry biomass yield. Liming of acid soil increased the Plant height, fresh biomass, dry biomass, grain yields, harvest index and P-uptake of barley (Achalu et al 2012). This increments related to the increase in soil fertility and reduction of the toxic concentration of acidic cations. This in turn, improves plant growth, most likely resulted from the enhanced conditions for seedling growth, and also helps in raising $\mathrm{pH}$ of the soil which reduces the effect of acidity on the performance of the crop.

Table: 2 Effects of lime on yield of some main crops

\begin{tabular}{llllll}
\hline Crops & \multicolumn{2}{l}{ EA $(\mathrm{cmol} \mathrm{kg})$} & Lime applied $\left(\mathrm{tha}^{-1}\right)$ & Yield $\left(\mathrm{t} \mathrm{ha}^{-1}\right)$ & Reference \\
\cline { 2 - 3 } & Before & After limed & & & \\
\hline Barley & 1.32 & 0.1 & 2.2 & 2.895 & Temasgen et al.,2017 \\
Soybean & 2.72 & 1.52 & 3.457 & 1.023 & Tolessa et al.,2018 \\
Common Bean & 5.19 & 2.72 & 9.0 & 0.849 & Hipha et al.,2013 \\
\hline
\end{tabular}

Where, EA= exchangeable acidity

Table: 3 Mean grain yield, Biomass, pod harvest index (PHI), Harvest index (HI) \& hundred seed weight (HSW) of common bean genotype as affected by lime application (Hirpa et al.,2013)

Mean values within a column that share similar letters are not significantly different at $\mathrm{P}<0.05$.

\begin{tabular}{lllllll}
\hline Treatments & GY $(\mathrm{g} / \mathrm{p})$ & AGB $(\mathrm{t} / \mathrm{ha})$ & BY(t/ha) & PHI & HI & HSW \\
\hline Unlimed & $7.4^{\mathrm{b}}$ & $1.9^{\mathrm{b}}$ & $3.6^{\mathrm{b}}$ & $1.01^{\mathrm{a}}$ & $0.33^{\mathrm{a}}$ & $18.8^{\mathrm{b}}$ \\
Limed & $10.3^{\mathrm{a}}$ & $2.6^{\mathrm{a}}$ & $5.3^{\mathrm{a}}$ & $1.05^{\mathrm{a}}$ & $0.34^{\mathrm{a}}$ & $19.5^{\mathrm{a}}$ \\
PR & 8.9 & 2.3 & 4.6 & 22.9 & 0.33 & 19.1 \\
Mean & 25.7 & 25.7 & 27.6 & 3.81 & 2.9 & 3.5 \\
CV $(\%)$ & 9.6 & 9.5 & 19.97 & 1.03 & 11.6 & 5.3 \\
\hline
\end{tabular}

Where, $\mathrm{PHI}=$ pod harvest index, $\mathrm{HI}=$ Harvest index, $\mathrm{HSW}=$ hundred seed weight, $\mathrm{GY}=$ grain yield, $\mathrm{AGB}=\mathrm{above}$ ground biomass, $\mathrm{PR}=$ percent reduction, $\mathrm{CV}=$ co-efficient of variation 
Table: 4 TSW, NSPS and HLW results from barley showing gradual increase as lime application rates were increased from 0 to 2.2 tons per hectare (Temasgen et al., 2016).

\begin{tabular}{llll}
\hline Lime rate $\left(\mathrm{t} \mathrm{ha}^{-1}\right)$ & TSW $(\mathrm{g})$ & NSPS & HLW \\
\hline 0 & $43.4^{\mathrm{c}}$ & $34.3^{\mathrm{d}}$ & $63.3^{\mathrm{b}}$ \\
0.55 & $45.7^{\mathrm{b}}$ & $40^{\mathrm{c}}$ & $64.2^{\mathrm{a}}$ \\
1.1 & $47.3^{\mathrm{ab}}$ & $43.3^{\mathrm{b}}$ & $64.5^{\mathrm{a}}$ \\
1.65 & $47.6^{\mathrm{a}}$ & $45.9^{\mathrm{ab}}$ & $64.8^{\mathrm{a}}$ \\
2.2 & $48.1^{\mathrm{a}}$ & $47.1^{\mathrm{a}}$ & $64.8^{\mathrm{a}}$ \\
\hline LSD $(0.05)$ & 1.7 & 3.1 & 0.8 \\
\hline
\end{tabular}

*Mean values within a column that share similar letters are not significantly different at $\mathrm{P}<0.05$.

Where, TSW $=$ Thousand seed weight, NSPS $=$ number of seeds per spike and HLW= hectolitre weight, LSD $=$ list significant different.

On the contrary, lime reacts slowly with soil to release fixed plant nutrients from alumunium and manganisium which is not directly absorbed by the plants. Therefore, plants are unable access required amount of nutrients in the critical yield-forming period. Hence, an integrated approach, combining application of lime with an application of inorganic fertilizer specifically phosphorus is a good strategy for increasing crop productivity under acidic soils. Such combination also contributed to the improvement of chemical and biological properties and also nutrient status of the soil.

Temesgen et al. (2017) investigated that $1.65 \mathrm{t} / \mathrm{ha}$ lime and $20 \mathrm{~kg} / \mathrm{ha}$ phosphorus application could give profitable yield, which was on par with application of $2.2 \mathrm{t} / \mathrm{ha}$ lime and $30 \mathrm{~kg} / \mathrm{ha}$ phosphorus and this combination could possibly reduce the cost of production in the barley cultivation. Workneh et al. (2013) were also tested the effect of lime and phosphorus fertilizers on grain yield and yield component of soybean, and they strongly suggested using combination of lime and phosphorus to achieve highest yield. It is clear from the results of their study that some amount of the required phosphorus fertilizer could be released from fixation of $\mathrm{P}$ by alumunium and manganisium, because of lime improved the availability of phosphorus and reduced its cost by reducing the external application of Phosphorus.

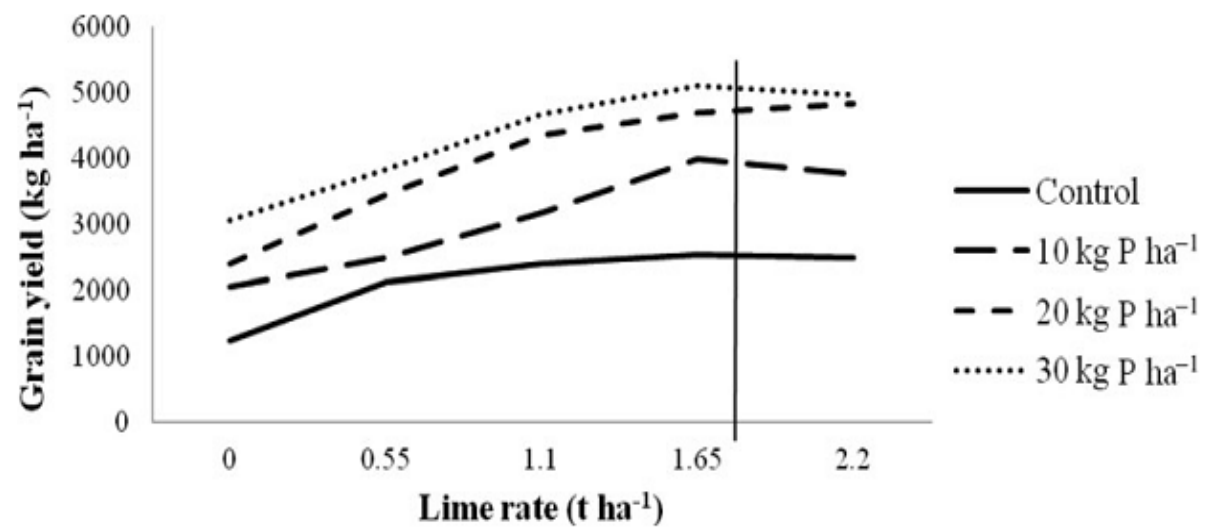

Figure 2.Yield results of barley showing gradual increase as lime and phosphorus application rates were increased from 0 to 1.65 tons and $0-20 \mathrm{~kg} P$ per hectare (Temasgen et al., 2016).

\section{CONCLUSION}

High amount of precipitation that exceeds evapo-transpiration that leaches appreciable amounts of exchangeable bases from the soil surface, crop management practices, removal of organic matter and continuous application of acid forming fertilizers, microbial production of nitric and sulfuric acids are among some of the factors that contribute to soil acidity, and leaching of cations in soils is most responsible for increased soil acidity, have adverse effects on the environment and can threaten human health as well as in food safety and quality. Limes and fertilizers are needed for highly acidic soil, particularly in phosphorus poor soils. Compared to chemical fertilizer alone, combination of lime with minimum chemical fertilizer specifically phosphorus are considered an economic and environmentally-friendly alternative, and have longer- lasting effects. While the general effects of lime application on soils, have been well documented such as increasing soil $\mathrm{pH}$, available phosphorus, cation exchange capacity, basic cations, microbial activity, organic carbon, total nitrogen, and decreasing leaching of nutrients, exchangeable alumunium and acidity. However, the effect of limes on soils is likely to be strongly dependent on lime composition, which depends on liming materials, application time and soil moisture at the time of application. Furthermore, lime application work very slowly to release nutrients from fixation. Therefore, plants are unable access required amount of nutrients in the critical yield forming period. Hence, an integrated approach, combining application of lime with an application of inorganic fertilizer is a good strategy for increasing crop productivity 
under acidic soils.

\section{REFERENCES}

Abdenna D., Ch. Negassa and G. Tilahun, 2007. Inventory of soil acidity status in crop lands of Central and Western Ethiopia. Utilization of diversity in land use systems: Sustainable and organic approaches to meet human needs. A paper presented on Tropentag, October 9-11, 2007 Witzenhausen, Germany.

Abubakari F., M. Tetteh, O. Tuffour, A. Aduwu and A. Abubakari, 2016. Strategies for improving nodulation and nitrogen fixation of leguminous crops to enhance production in smallholder farming systems. Journal of Global Agriculture and Ecology, 4:185-190.

Achalu Ch., Gebrekidan, H., Kibret, K. and Tadesse, A., 2012. Response of barley to liming of acid soils collected from different land use systems of Western Oromia, Ethiopia. Journal of Biodiversity and Environmental Sciences, 2(7), pp.1-13.

Adane B., 2014. Effects of liming acidic soils on improving soil properties and yield of haricot bean. Journal of Environmental \& Analytical Toxicology, 5:1-4.

Álvarez, E., Viadé, A. and Fernández, M. L. (2009). Effect of liming with different sized limestone on the forms of aluminium in a Galician soil (NW Spain).Geoderma152:1-8.

Andric L., M. Rastija, T. Teklic and V. Kovacevic, 2012. Response of maize and soybeans to liming. Turkish Journal of agriculture and forestry, 36:415-420.

Anetor O. and E. Akinrinde, 2006. Response of soybean [Glycine max (L.) Merrill] to lime and phosphorus fertilizer treatments on an acidic alfisol of Nigeria. Pakistan Journal of Nutrition, 5: 286-293.

Bohn L., L. McNeal and A. O’Connor, 2001. Soil chemistry, $3^{\text {rd }}$ ed. John Wiley and Sons, Inc, New York. 307p.

Brady C. and R. Weil, 2002. The nature and properties of soils, 13th. Pearson education (Singapore) Pte. Ltd. Indian Branch, 482: 621-624.

Buri, M. M., Wakatsuki, T. and Issaka, R. N. (2005). Extent and management of low pH soils in Ghana.Soil Science and Plant Nutrition51:755-759.

Caires F., S. Churka, J. Garbuio, A. Ferrari and A. Morgano, 2006. Soybean yield and quality a function of lime and gypsum applications. Scientia Agricola, 63: 370-379.

Fageria K. and C. Baligar, 2008. Ameliorating soil acidity of tropical Oxisols by liming for sustainable crop production. Advances in agronomy, 99: 345-399.

Havlin L., D. Beaton, L. Tisdale and L. Nelson, 1999. Soil Fertility and Fertilizers: An introduction to nutrient management, (6th eds.), Pearson Education, India, 499p.

Hirpa L., D. Niguse, G. Setegn, B. Geremew and M. Firew, 2013. Response to soil acidity of common bean genotypes (Phaseolus vulgaris L.) under field conditions at Nedjo, western Ethiopia. Science, Technology and Arts Research Journal, 2: 03-15

Johnston E., 2004. Soil acidity-resilience and thresholds. Managing Soil Quality: Challenges in Modern Agriculture, pp. 35-44.

Kisinyo O., 2016. Long term effects of lime and phosphorus application on maize productivity in an acid soil of Uasin Gishu County, Kenya. Sky Journal of Agricultural Research, 5: 48 - 55.

Kochian V., A. Hoekenga and A. Pineros, 2004. How do crop plants tolerate acid soils? Mechanisms of aluminum tolerance and phosphorous efficiency. Annu. Rev. Plant Biol., 55: 459-493.

McBride, M.B. 1994. Environmental Chemistry of Soils. Oxford University Press. New York.

Meng, C., Xiaonan, L., Zhihong, C., Zhengyi, H. and Wanzhu, M. (2004). Long-term effects of lime application on soil acidity and crop yields on arid soil in Central Zhejiang.Plant and Soil265:101-109.

Mesfin K., Y. Belay, and H. Abera, 2014. Effects of Liming and Phosphorus Levels on Yield and Yield Components of Haricot Bean (Pharsalus vulgarism L.) Varieties on Nitosols at Wolaita Zone, Ethiopia. Asian Journal of Crop Science, 6: 245-253.

Moody W and P. Cong, 2008. Soil constraints and management practice: guidelines for Sustainable management for tropical upland soils. Australian Center for Agricultural Research (ACIAR), Australia 86p.

Murata R., S. Hammes and E. Zharare, 2002. Soil amelioration effects on nutrient availability and productivity of groundnut on acid sandy soils of Zimbabwe. Experimental agriculture, 38: 317-331.

Nekesa O., R. Okalebo, O. Othieno, N. Thuita, M. Kipsat, A. Bationo, N. Sanginga, J. Kimettu and B. Vanlauwe, 2005. The potential of Minjingu phosphate rock from Tanzania as a liming material : effect on maize and bean intercrop on acid soils of western Kenya. African Crop Science Conference Proceedings, 7:1121- 1128.

Temasgen D., G. Alemu, A. Adella and D. Tolessa, 2017. Effect of lime and phosphorus fertilizer on Acid soils and barley (Hordeum vulgare l.) performance in the central highlands of Ethiopia. Experimental Agriculture, 53: 432-444.

TSO, 2010. Fertilizer manual (8th Ed.). Department for Environment, Food and Rural Affairs. United Kingdom (UK)

Workneh B., K. Tesfu and D. Jafer, 2013. Growth and Nodulation Response of Soybean (Glycine max L.) to Lime, Bradyrhizobium japonicum and Nitrogen Fertilizer in Acid Soil at Melko, South Western Ethiopia. 
International Journal of Soil Science, 8:25- 31.

Zerihun A and A. Tolera, 2014. Yield response of faba bean to fertilizer rate, Rhizobium inoculation and lime rate at Gedo highland, western Ethiopia. Global Journal of Crop, Soil Science and Plant Breeding, 2:134-139. 